\title{
Upaya A wal Optimasi Jumlah Kendaraan Angkut pada Kasus Umum Pengangkutan Obyek dari n Titik Asal ke 1 Titik Pengumpulan
}

\author{
Preliminary Attempt for Optimizing Transportation Vehicle Number \\ in General Case of Transporting Objects from n Origin Points to 1 \\ Collection Point
}

\author{
Hitapriya Suprayitno $^{1, \text { a) }}$ \& Ria Asih Aryani Soemitro ${ }^{2, b)}$ \\ ${ }^{1)}$ Departemen Teknik Sipil, Institut Teknologi Sepuluh November, Surabaya \\ ${ }^{2)}$ Departemen Teknik Sipil, Institut Teknologi Sepuluh November, Surabaya \\ Koresponden : ${ }^{\text {a) }}$ suprayitno.hita@gmail.com, ${ }^{\text {b) }}$ soemitroraa@ gmail.com
}

\begin{abstract}
ABSTRAK
Kasus umum pengangkutan obyek dari $\mathrm{n}$ titik asal ke 1 titik pengumpulan banyak dijumpai sehari-hari. Kasus pengangkutan sampah padat perkotaan dari TPS ke TPA termasuk kedalam golongan kasus ini. Jadi, metoda optimasi untuk kasus ini perlu untuk dibangun. Penelitian ini telah menghasilkan suatu Metoda Optimasi. Metoda ini mengandung 2 langkah utama. Langkah pertama berupa identifikasi titik tidak bisa dilayani. Langkah kedua berupa penyusunan rute truk pengangkutan. Langkah ini dilakukan berulang sampai seluruh Titik Asal disinggahi. Penyusunan rute pengangkutan dilakukan dengan memaksimalkan jumlah singgahan tanpa melanggar kendala waktu kerja truk, berarti Rute ditentukan dengan selalu memilih tujuan berikut terdekat. Metoda ini telah di-uji-coba dengan hasil yang memuaskan. Metoda ini diberi nama : Optimasi Jumlah Kendaraan Pesinggah dengan Kendala Waktu Kerja Kendaraan.
\end{abstract}

Kata Kunci : manajemen aset infrastruktur, manajemen operasi, infrastruktur sampah padat, optimasi.

\section{PENDAHULUAN}

Kasus umum Pengumpulan Barang dari n Titik Asal ke 1 Titik Pengumpulan mempunyai variasi yang cukup banyak. Variasi ini tergantung dari sistem pengangkutan, waktu kerja, kapasitas truk, dan yang lain. Kasus semacam ini banyak dijumpai dalam kehidupan sehari-hari, terutama dalam masalah Logistik. Salah satu contoh kasus ini misalnya permasalahan yang dihadapi oleh suatu perusahaan supermarket yang harus mengumpulkan barang dari para pemasok di beberapa titik asal ke 1 buah gudang distribusi regional. Contoh yang lain misalnya permasalahan yang dihadapi oleh perusahaan ekspedisi yang harus mengumpulkan seluruh barang kiriman dari lokasi para agen ke pusat pengiriman regional.

Dalam urusan Pengelolaan Infrastruktur Pekerjaan Umum kasus ini juga terjadi. Contoh penting dalam hal ini adalah Sistem Pengangkutan Sampah Padat Perkotaan dari Tempat Pembuangan Sementara (TPS) ke Tempat Pembuangan Akhir (TPA). Sistem Pengangkutan Sampah Padat ini secara umum bisa dibedakan menjadi 2 cara : Hauled Container System (HCS) dan Stationary Container System (SCS). Bagi Kota Surabaya, Sistem HCS sudah dipraktekkan lama, sedangkan Sistem SCS relatif baru saja mulai diterapkan. Hal ini 
merupakan salah satu bagian dari Aspek Manajemen Operasi pada Manajemen Aset Infrastruktur.

Oleh karena itu Metoda Optimasi Jumlah Kendaraan Pengangkut pada Kasus Umum Pengumpulan Barang dari n Titik Asal ke 1 Titik Pengumpulan perlu untuk disusun. Pengetahuan ini sangat dibutuhkan bagi Ilmu Manajemen Operasi Infrastruktur. Upaya ini merupakan upaya awal, sehingga banyak hal masih sangat disederhanakan.

\section{STUDI PUSTAKA}

\section{Optimasi Kasus Linier dan Kasus Jaringan.}

Permasalahan ini, dilihat dari sudut pandang Riset Operasional, termasuk kedalam golongan Permasalahan Linier dan Permasalahan Jaringan. Metoda Optimasi yang sudah terbangun didalam golongan ini adalah : Programasi Linier, Programasi Linier Khusus (Permasalahan Transportasi, Permasalahan Transhipment, Permasalahan Penugasan), Integer Programming - dengan variasi pengembangannya, Travelling Salesman Problem, Knapsack Programming, Rute Terpendek - dengan variasi pengembangannya, Rute Terpanjang, Rentang Terpendek, Rentang Terpanjang, Arus Maksimum (Brandes \& Erlebach, 1998; Dimyati \& Dimyati, 1994; Goldberg, 2000; Hillier \& Lieberman, 1990; Indryani, Astana \& Suprayitno, 2004; Jaiswal, 1997; Khan, 1984; Srivastava \& Nema, 2006; Suprayitno \& Indryani, 1997; Suprayitno \& Indryani, 1997; Suprayitno, 1999; Suprayitno, 2003; Taha, 1992).

Teori Graf, walaupun tidak secara spesial ditujukan untuk Optimasi masalah Jaringan, didalamnya secara sangat terbatas juga membahas Optimasi Jaringan. Metoda perhitungan yang ada pada Teori Graf ini relatif tidak praktis (Bondy \& Murty, 1982; Brandes \& Erlebach, 1998; Suprayitno, 2008; Suprayitno, 2009; Suprayitno, 2010; Suprayitno, Mochtar \& Wicaksono, 2009; Suprayitno, Mochtar \& Wicaksono, 2009a).

Matematik Diskrit adalah cabang ilmu matematika yang dibangun untuk keperluan Ilmu Informatika. Ilmu ini merupakan kumpulan kasus-kasus ilmu matematika yang bersifat diskrit, seperti : logika, himpunan, matriks, algoritma, aljabar bolean, teori graf dan yang lain. Didalamnya membahas kasus Optimasi Kasus Diskrit juga (Munir, 2003; Suprayitno, 2014).

Selain itu dikenal Teknik Aljabar Maks-Plus dan Aljabar Min-Plus yang bisa digunakan untuk melakukan beberapa Perhitungan Optimasi Kasus Jaringan (Bacelli et al, 1992), (Schutter \& Boom, 2008; Vries, Schutter \& Moor, 2008; Suprayitno, 2010; Suprayitno, Mochtar \& Wicaksono, 2014; Suprayitno, Mochtar \& Wicaksono, 2014a).

Metoda Optimasi kasus ini tidak ditemukan pada referensi-referensi tersebut diatas. Oleh karena itu penyusunan Metoda Optimasi masih diperlukan.

\section{Metoda Matriks Khusus bagi Analisis Jaringan Transportasi}

Metoda Matriks Khusus telah dibangun untuk digunakan dalam Perhitungan Optimasi Kasus Jaringan. Metoda ini menggunakan matriks bujur sangkar dengan 3 macam bentuk : matriks dasar, matriks ekspansi dan matriks indikatif. Dilihat dari isi sel matriks, dikenal dua macam matriks : matriks diagonal dan matriks non diagonal. Metoda Matriks Khusus ini sangat praktis untuk digunakan dengan menggunakan perangkat lunak tipe spread-sheet (Suprayitno, 2008; Suprayitno, 2014; Suprayitno, 2015).

Metoda Perhitungan bagi Optimasi ini dibangun dengan semaksimal mungkin menggunakan Metoda Matriks Khusus diatas.

\section{PENYUSUNAN METODA OPTIMASI AWAL}

Upaya penyusunan Metoda Optimasi Awal ini, untuk memudahkan proses penyusunan Metoda Optimasi, dibatasi untuk Kasus Fiktif yang sangat disederhanakan. Dalam upaya awal 
ini, meskipun kasus yang ditangani adalah Kasus Pengangkutan dari n Titik Asal ke 1 Titik Pengumpulan melalui Jaringan Jalan dan dengan menggunakan suatu Armada Kendaraan Pengangkut, banyak hal dihilangkan untuk menyederhanakan masalah. Hal-hal yang dihilangkan pada Optimasi Tahap Awal ini adalah : Jaringan Jalan dianggap tidak ada, Kapasitas Kendaraan Pengangkut dianggap tidak ada, Volume Barang Angkutan dianggap tidak ada. Jadi masalah ini sebetulnya adalah masalah persinggahan kendaraan pada $\mathrm{n}$ titik. Metoda Perhitungan akan dibangun dengan menggunakan Metoda Matriks Khusus.

\section{Kasus Fiktif}

Kasus Fiktif dirumuskan sebagai berikut. Suatu Permasalahan Pengangkutan dengan beberapa Titik Asal (TA), 1 Depot Truk (D) dan 1 Titik Pengumpulan (TP). Jaringan Jalan, Volume Barang Angkutan dan Kapasitas Kendaraan Pengangkut dianggap tidak ada atau diabaikan. Dengan demikian, Kasus Fiktif Awal ini sebetulnya hanyalah Masalah Persinggahan Titik Asal oleh suatu Armada Kendaraan. Jarak dalam waktu tempuh antar seluruh Titik Asal-Tujuan : D, TP dan TA diketahui. Waktu henti di TA dan TP tidak diperhitungkan. Lama kerja Armada Kendaraan dalam 1 hari diketahui. Dalam 1 hari, seluruh TA harus sudah disinggahi. Seluruh TA sudah siap untuk disinggahi pada jam berapa saja. Dengan demikian Optimasi hanya didasarkan pada Minimalisasi Jumlah Kendaraan yang dibutuhkan untuk Singgah di seluruh TA dengan Batasan Waktu Kerja satu hari.

\section{Model Grafis}

Permasalahan ini bisa dimodelkan dalam bentuk Model Grafis. Bentuk Model Grafis disampaikan pada Gambar 1 sebagai berikut.

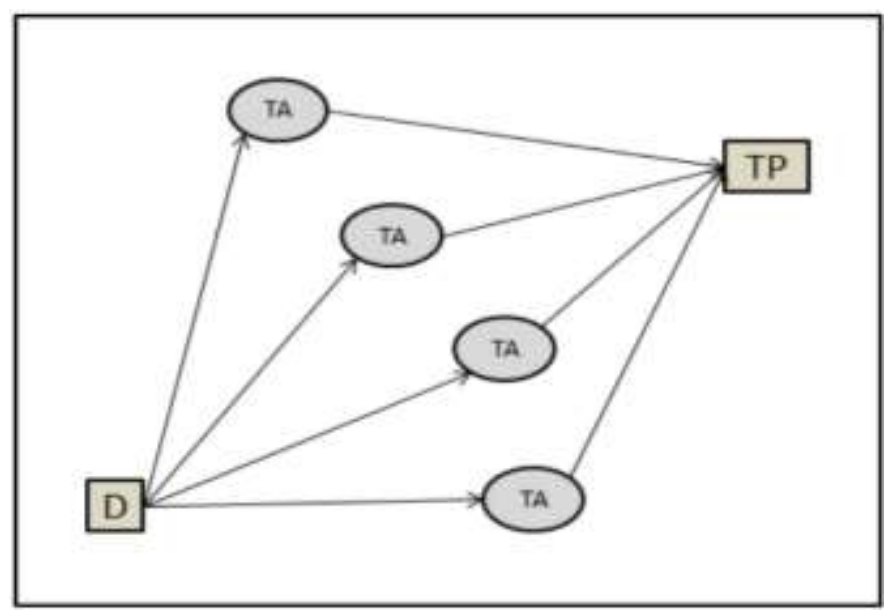

Gambar 1. Model Grafis Kasus Penelitian

\section{Model Matematis Optimasi}

Optimasi Kasus ini berupa meminimalkan jumlah Kendaraan yang harus dioperasikan untuk mendatangi seluruh TA, dengan seluruh Kendaraan berasal dari D dan Persinggahan terkahir adalah di TP. Setiap Rute Persinggahan yang ditentukan, terkena kendala batasan Waktu Kerja Kendaraan.

Teknik Optimasi yang digunakan didasarkan pada Ketentuan sebagai berikut. Meminimalkan Jumlah Kendaraan baru bisa tercapai kalau setiap Rute Persinggahan dirancang dengan Memaksimalkan Jumlah Kunjungan TA.

Dengan demikian Model Matematis Optimasi bisa dituliskan sebagai berikut.

Min. $\mathrm{Z}=$ jumlah $\mathrm{R}_{\mathrm{i}}$

Kendala :

$$
\mathrm{d}_{\mathrm{Ri}}=\mathrm{d}_{\mathrm{D}-\mathrm{TAi}}+\mathrm{S}\left(\mathrm{d}_{\mathrm{Tai}-\mathrm{TAi}+1}+\mathrm{d}_{\mathrm{Tai}+1-\mathrm{TAi}+2} \ldots . .+\mathrm{d}_{\mathrm{Tan}-1-\mathrm{TAn}}\right)+\mathrm{d}_{\mathrm{Tan}-\mathrm{TP}}(2) \mathrm{m}
$$




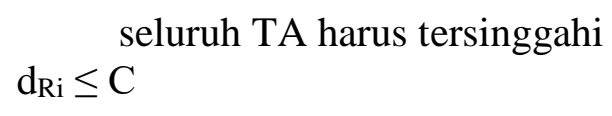

Notasi :

$$
\begin{array}{ll}
\mathrm{R}_{\mathrm{i}} & \text { : Rute Pengangkutan } \mathrm{i} \\
\mathrm{d}_{\mathrm{Ri}} & \text { : Panjang Waktu Tempuh Rute Pengangkutan } \mathrm{i} \\
\mathrm{d}_{\mathrm{D}-\mathrm{TA} 1} & : \text { Jarak Waktu Tempuh dari Titik D ke Titik TA1 } \\
\mathrm{C} & \text { : Konstanta, dalam hal ini berupa Nilai terkait Lama Kerja } \\
& \text { Kendaraan per hari }
\end{array}
$$

\section{Algoritma Optimasi Pemecahan Masalah}

Algoritma disusun berdasarkan Tujuan dan Teknik Optimasi yang sudah diuraikan diatas. Oleh karena itu Rancangan Algoritma menjadi sebagai berikut.

- Periksa keberadaan Titik Asal yang tidak bisa dilayani.

- Tentukan Rute Pengangkutan 1 dengan jumlah TA maksimal tanpa melanggar Kendala Waktu Kerja Kendaraan. Selanjutnya tentukan TA sisa yang belum didatangi.

- Langkah kedua dilakukan berulang-ulang, sampai seluruh TA telah didatangi.

Selanjutnya penentuan Rute Pengangkutan Optimal dilakukan dengan mengikuti prosedur sebagai berikut.

- Ambil TA terdekat 1, kemudian disebut sebagai TA Terdatangi 1

- Ambil TA terdekat dari TA Terdatangi 1.

- Cek Jarak Total D - TAi - TP.

- Bila Jarak Total memenuhi syarat, ambil ulangi Langkah kedua.

- Bila Jarak Total tidak memenuhi syarat, gugurkan TA Terdatangi terakhir.

\section{Metoda Perhitungan}

Seluruh Metoda Perhitungan ini dibangun dengan menggunakan Metoda Matriks Khusus bagi Analisis Jaringan Transportasi. Data Jarak antar titik-titik asal tujuan (D, TAn, TP) dipresentasikan dengan menggunakan Matriks Jarak.

Perhitungan Identifikasi Titik Asal Tidak Layak Dilayani dilakukan dengan menggunakan Matriks Identifikasi, sebagai berikut.

$$
\begin{aligned}
& \text { mei.I }=m . D+D_{i}+D_{j}+I R_{i}+I_{j}+S I \\
& \mathrm{DR}_{\mathrm{i}}=\mathrm{m}_{\mathrm{D}, \mathrm{TAi}}+\mathrm{m}_{\mathrm{TAi}, \mathrm{TP}} \\
& D_{\mathrm{j}}=\mathrm{m}_{\mathrm{D}, \mathrm{TAi}}+\mathrm{m}_{\mathrm{TAi}, \mathrm{TP}} \\
& \mathrm{IR}_{\mathrm{i}}=0, \forall \mathrm{IR}_{\mathrm{i}}<\mathrm{WK} \text {, lain } 1 \\
& \mathrm{IC}_{\mathrm{j}}=0, \forall \mathrm{IC}_{\mathrm{j}}<\mathrm{WK} \text {, lain } 1 \\
& \mathrm{SIR}=\sum \mathrm{IR}_{\mathrm{i}} \\
& \mathrm{SIC}=\sum \mathrm{IC}_{\mathrm{j}} \\
& \mathrm{WK}=\mathrm{C}
\end{aligned}
$$

Notasi :

$$
\begin{aligned}
\text { mei.I } & =\text { matriks identifikasi TA Tak Layak Terlayani } \\
\mathrm{m}_{\mathrm{D}} & =\text { matriks data jarak tempuh antar titik } \\
\mathrm{DR}_{\mathrm{i}} & =\text { jarak lintasan D-TAn-TP dalam baris } \\
\mathrm{DC}_{\mathrm{j}} & =\text { jarak lintasan D-TAn-TP dalam kolom } \\
\mathrm{IR}_{\mathrm{i}} & =\text { identifikasi TA Tak Terlayani dalam baris } \\
\mathrm{IC}_{\mathrm{j}} & =\text { identifikasi TA Tak Terlayani dalam kolom } \\
\mathrm{SI} & =\text { jumlah TA teridentifikasi } \\
\mathrm{m}_{\mathrm{j}} & =\text { nilai sel i,j } \\
\mathrm{WK} & =\text { waktu kerja kendaraan }
\end{aligned}
$$




$$
\mathrm{C} \quad=\text { konstanta }
$$

Perhitungan Rute Kendaraan Persinggahan dilakukan dengan menggunakan Tabel bertahap, seperti disampaikan pada bab berikut.

\section{UJI COBA METODA OPTIMASI}

Uji Coba Metoda Optimasi dilakukan dengan menggunakan Kasus Fiktif yang sangat disederhanakan. Perhitungan terdiri dari 3 macam langkah : Langkah TA tidak terlayani, Langkah Penyusunan Rute (beberapa tahap secukupnya) dan Langkah Hasil Perhitungan.

\section{Kasus Uji Coba}

Kasus Fiktif mengandung 1 Depot Truk (D), 1 Titik Pengumpulan (TP) dan 9 Titik Asal (TA). Jarak Tempuh antar masing-masing titik diketahui dan disampaikan pada Tabel 1 dibawah ini. Waktu Kerja Maksimum dari D-TA-TP adalah 15 jam. Jumlah Truk yang tersedia mencukupi.

Tabel 1. Matriks Data Waktu Tempuh antar Titik Asal Tujuan (jam)

\begin{tabular}{|c|c|c|c|c|c|c|c|c|c|}
\hline & D & TP & TA1 & TA2 & TA3 & TA4 & TA5 & TA6 & TA7 \\
\hline D & 0 & 5 & 8 & 7 & 6 & 4 & 5 & 3 & 9 \\
\hline TP & 5 & 0 & 6 & 6 & 4 & 3 & 2 & 5 & 7 \\
\hline TA1 & 8 & 6 & 0 & 3 & 5 & 2 & 4 & 5 & 6 \\
\hline TA2 & 7 & 6 & 3 & 0 & 4 & 3 & 2 & 6 & 1 \\
\hline TA3 & 6 & 4 & 5 & 4 & 0 & 7 & 4 & 3 & 3 \\
\hline TA4 & 4 & 3 & 2 & 3 & 7 & 0 & 5 & 2 & 6 \\
\hline TA5 & 5 & 2 & 4 & 2 & 4 & 5 & 0 & 4 & 8 \\
\hline TA6 & 3 & 5 & 5 & 6 & 3 & 2 & 4 & 0 & 2 \\
\hline TA7 & 9 & 7 & 6 & 1 & 3 & 6 & 8 & 2 & 0 \\
\hline
\end{tabular}

\section{Perhitungan 1 : Pemeriksaan TA Tidak Layak Dilayani}

Pemeriksaan TA tidak layak dilayani karena jumlah waktu tempuh total D-TA-PP melebihi kendala waktu yang ditetapkan sebesar 15 jam. Perhitungan dilakukan dengan menggunakan Matriks Identifikasi, seperti disampaikan pada Tabel 2 sebagai berikut. Dari perhitungan bisa terlihat bahwa TA7 tidak layak dilayani, karena waktu tempuh minimal = 16 $>15$.

Tabel 2. Matriks Identifikasi TA Tidak Layak Dilayani

\begin{tabular}{|c|c|c|c|c|c|c|c|c|c|c|c|}
\hline & D & $\mathbf{T P}$ & TA1 & TA2 & TA3 & TA4 & TA5 & TA6 & TA7 & $\mathbf{d}_{\text {D-TA-TP }}$ & Cek \\
\hline D & 0 & 5 & 8 & 7 & 6 & 4 & 5 & 3 & 9 & & \multirow{2}{*}{$<15$} \\
\hline TP & 5 & 0 & 6 & 6 & 4 & 3 & 2 & 5 & 7 & & \\
\hline TA1 & 8 & 6 & 0 & 3 & 5 & 2 & 4 & 5 & 6 & 14 & ok \\
\hline TA2 & 7 & 6 & 3 & 0 & 4 & 3 & 2 & 6 & 1 & 13 & ok \\
\hline TA3 & 6 & 4 & 5 & 4 & 0 & 7 & 4 & 3 & 3 & 10 & ok \\
\hline TA4 & 4 & 3 & 2 & 3 & 7 & 0 & 5 & 2 & 6 & 7 & ok \\
\hline TA5 & 5 & 2 & 4 & 2 & 4 & 5 & 0 & 4 & 8 & 7 & ok \\
\hline TA6 & 3 & 5 & 5 & 6 & 3 & 2 & 4 & 0 & 2 & 8 & ok \\
\hline TA7 & 9 & 7 & 6 & 1 & 3 & 6 & 8 & 2 & 0 & 16 & $\mathrm{x}$ \\
\hline$d_{\text {D-TA-TP }}$ & & & 14 & 13 & 10 & 7 & 7 & 8 & 16 & & \\
\hline Cek & & & ok & ok & ok & ok & ok & ok & $\mathrm{x}$ & & \\
\hline
\end{tabular}




\section{Matriks Data Waktu Tempuh Baru}

Dengan TA7 telah diketahui sebagai TA Tidak Layak Dilayani, maka Jarak dari TA7 kemanapun diganti dengan Nilai 999. Didapatkan Matriks Data Baru seperti disampaikan pada Tabel 3 sebagai berikut.

Tabel 3. Matriks Data Baru setelah Langkah Identifikasi TA Tak Layak Dilayani

\begin{tabular}{|c|c|c|c|c|c|c|c|c|c|}
\hline & D & TP & TA1 & TA2 & TA3 & TA4 & TA5 & TA6 & TA7 \\
\hline D & 0 & 5 & 8 & 7 & 6 & 4 & 5 & 3 & 999 \\
\hline TP & 5 & 0 & 6 & 6 & 4 & 3 & 2 & 5 & 999 \\
\hline TA1 & 8 & 6 & 0 & 3 & 5 & 2 & 4 & 5 & 999 \\
\hline TA2 & 7 & 6 & 3 & 0 & 4 & 3 & 2 & 6 & 999 \\
\hline TA3 & 6 & 4 & 5 & 4 & 0 & 7 & 4 & 3 & 999 \\
\hline TA4 & 4 & 3 & 2 & 3 & 7 & 0 & 5 & 2 & 999 \\
\hline TA5 & 5 & 2 & 4 & 2 & 4 & 5 & 0 & 4 & 999 \\
\hline TA6 & 3 & 5 & 5 & 6 & 3 & 2 & 4 & 0 & 999 \\
\hline TA7 & 999 & 999 & 999 & 999 & 999 & 999 & 999 & 999 & 0 \\
\hline
\end{tabular}

\section{Perhitungan 2 : Penyusunan Rute 1}

Perhitungan Penyusunan Rute 1 secara rinci disampaikan dibawah ini. Perhitungan Penyusunan Rute 1 disampaikan dalam bentuk tabel pada pada Tabel 4 dibawah ini.

- Cari TA terdekat dengan D : TA6 jarak = 3

- Hitung Jarak sampai ke TP : $3+5=8$

- Jarak masih memenuhi syarat, berarti TA6 masih bisa dikembangkan

- Cari TA terdekat dengan TA6 : TA4 jarak $=2$

- Hitung Jarak sampai ke TP : $3+2+3=8$

- Jarak masih memenuhi syarat, berarti TA4 bisa dikembangkan.

- Cari TA terdekat dengan TA4 : TA1, jarak $=2$

- Hitung Jarak sampai ke TP=3+2+2+6=13

- Jarak masih memenuhi syarat, berarti TA1 masih bisa dikembangkan

- Cari TA terdekat dengan TA1 : TA2, jarak = 3

- Hitung Jarak sampai TP $=3+2+2+3+6=16$

- Jarak tidak memenuhi syarat, berarti TA2 digugurkan.

Tabel 4. Perhitungan Penyusunan Rute 1

\begin{tabular}{|c|c|c|c|c|c|c|c|}
\hline Rute & Jarak & Rute & Jarak & Rute & Jarak & Rute & Jarak \\
\hline D-TA6 & 3 & & \begin{tabular}{|l|}
3 \\
\end{tabular} & & 3 & & \begin{tabular}{|l|}
3 \\
\end{tabular} \\
\hline TA6-TP & 5 & TA6-TA4 & 2 & & 2 & & 2 \\
\hline Panjang & 8 & TA4-TP & 3 & TA4-TA1 & 2 & & 2 \\
\hline \multirow[t]{4}{*}{ Cek } & ya & Panjang & 8 & TA1-TP & 6 & TA1-TA2 & 3 \\
\hline & & Cek & ya & Panjang & 13 & TA2-TP & 6 \\
\hline & & & & Cek & ya & Panjang & 16 \\
\hline & & & & & & Cek & tidak \\
\hline
\end{tabular}

\section{Matriks Data Waktu Tempuh Baru Setelah Rute 1}

Penyelesaian Rute 1, menghasilkan TA6, TA4 dan TA1 harus disingkirkan dari perhitungan selanjutnya. Semua jarak yang melibatkan TA6, TA4 dan TA 1 diberi nilai 999. Matriks Data Baru disampaikan pada Tabel 5 sebagai berikut. 
Tabel 5. Matriks Data Baru, setelah Penyusunan Rute 1

\begin{tabular}{|c|c|c|c|c|c|c|c|c|c|}
\hline & D & TP & TA1 & TA2 & TA3 & TA4 & TA5 & TA6 & TA7 \\
\hline D & 0 & 5 & 999 & 7 & 6 & 999 & 5 & 999 & 999 \\
\hline TP & 5 & 0 & 999 & 6 & 4 & 999 & 2 & 999 & 999 \\
\hline TA1 & 999 & 999 & 0 & 999 & 999 & 999 & 4 & 999 & 999 \\
\hline TA2 & 7 & 6 & 999 & 0 & 4 & 999 & 2 & 999 & 999 \\
\hline TA3 & 6 & 4 & 999 & 4 & 0 & 999 & 4 & 999 & 999 \\
\hline TA4 & 999 & 999 & 999 & 999 & 999 & 0 & 999 & 999 & 999 \\
\hline TA5 & 5 & 2 & 999 & 2 & 4 & 999 & 0 & 999 & 999 \\
\hline TA6 & 999 & 999 & 999 & 999 & 999 & 999 & 999 & 999 & 999 \\
\hline TA7 & 999 & 999 & 999 & 999 & 999 & 999 & 999 & 999 & 0 \\
\hline
\end{tabular}

\section{Perhitungan 3 : Penyusunan Rute 2}

Perhitungan Penyusunan Rute 2 dilakukan dengan menggunakan Algoritma Penyusunan Rute Optimal seperti diatas. Rincian perhitungan disampaikan pada Tabel 6 dibawah ini. Perhitungan ini menghasilkan Rute sebagai berikut.

- Rute 2 : D - TA5 - TA2 - TP, Jarak $=13$.

Tabel 6. Perhitungan Penyusunan Rute

\begin{tabular}{|c|c|c|c|c|c|}
\hline Rute & Jarak & Rute & Jarak & Rute & Jarak \\
\hline D-TA5 & 5 & & 5 & & 5 \\
\hline TA5-TP & 2 & TA5-TA2 & 2 & & 2 \\
\hline Panjang & 7 & TA2-TP & 6 & TA2-TA3 & 4 \\
\hline \multirow[t]{3}{*}{ Cek } & ya & Panjang & 13 & TA3-TP & 6 \\
\hline & & Cek & ya & Panjang & 17 \\
\hline & & & & Cek & tidak \\
\hline
\end{tabular}

\section{Matriks Data Waktu Tempuh Baru Setelah Rute 2}

Matriks baru dihasilkan dengan menghilangkan TA5 dan TA2. Seluruh Nilai Jarak dari dan ke TA5 dan TA2 diubah menjadi 999. Matriks Data Baru disampaikan pada Tabel 7 sebagai berikut.

Tabel 7. Matriks Data Baru, setelah Penyusunan Rute 2

\begin{tabular}{|c|c|c|c|c|c|c|c|c|c|}
\hline & D & TP & TA1 & TA2 & TA3 & TA4 & TA5 & TA6 & TA7 \\
\hline D & 0 & 5 & 999 & 999 & 6 & 999 & 999 & 999 & 999 \\
\hline TP & 5 & 0 & 999 & 999 & 4 & 999 & 999 & 999 & 999 \\
\hline TA1 & 999 & 999 & 0 & 999 & 999 & 999 & 999 & 999 & 999 \\
\hline TA2 & 999 & 999 & 999 & 0 & 999 & 999 & 999 & 999 & 999 \\
\hline TA3 & 6 & 4 & 999 & 999 & 0 & 999 & 999 & 999 & 999 \\
\hline TA4 & 999 & 999 & 999 & 999 & 999 & 0 & 999 & 999 & 999 \\
\hline TA5 & 999 & 999 & 999 & 999 & 999 & 999 & 0 & 999 & 999 \\
\hline TA6 & 999 & 999 & 999 & 999 & 999 & 999 & 999 & 999 & 999 \\
\hline TA7 & 999 & 999 & 999 & 999 & 999 & 999 & 999 & 999 & 0 \\
\hline
\end{tabular}




\section{Perhitungan 4 : Penyusunan Rute 3}

Perhitungan Penyusunan Rute 3 dilakukan dengan metoda yang sudah dicoba diterapkan pada Penyusunan Rute 1 dan Rute 2. Rincian perhitungan disampaikan pada Tabel 8 dibawah ini. Perhitungan ini menghasilkan Rute 3 sebagai berikut.

- Rute $3: \mathrm{D}-\mathrm{TA} 3-\mathrm{TP}$, Jarak $=10$ jam.

Tabel 8. Perhitungan Penyusunan Rute 3

\begin{tabular}{|c|c|}
\hline Rute & Jarak \\
\hline D-TA3 & 6 \\
\hline TA3-TP & 4 \\
\hline Jarak & 10 \\
\hline Cek & ya \\
\hline
\end{tabular}

Seluruh TA telah disinggahi, Penyusunan Rute telah berhasil diselesaikan. Matrik Data Baru tidak perlu disusun ulang.

\section{Rangkuman Hasil Perhitungan}

Perhitungan telah diselesaikan, pokok-pokok Hasil Perhitungan secara ringkas disampaikan sebagai berikut :

TA tidak bisa dilayani : TA7.

Jumlah Kendaraan minimal : 3 buah.

Rute Pengangkutan :

- Rute 1 : D - TA6 - TA4 - TA 1 - TP - Panjang = 13 jam.

- Rute 2:D - TA5 - TA 2 - TP -Panjang = 13 jam.

- Rute $3: \mathrm{D}-\mathrm{TA} 3-\mathrm{TP}$ - Panjang = $10 \mathrm{jam}$.

\section{KESIMPULAN}

Bisa dimpulkan disini bahwa Tujuan Penelitian telah tercapai, karena Metoda Optimasi telah berhasil disusun.

Secara umum Metoda Optimasi mengandung 2 langkah utama : pertama Identifikasi Titik Asal Tidak Layak Dilayani, kedua Penyusunan Rute-Rute Persinggahan yang diperlukan secara bertahap. Penyusunan Rute dilakukan dengan pertimbangan memaksimalkan Jumlah Titik Singgah berdasar Pemilihan Rute, dengan Kendala Lama Waktu Kerja. Agar maksimalisasi persinggahan terpenuhi, sebagai syarat minimalisasi Jumlah Kendaraan Singgah, Penentuan Rute dilakukan dengan setiap kali memilih Titik Asal terdekat, sampai Waktu Kerja Kendaraan tidak tersisa lagi.

Berhubung Kasus yang ditangani masih berupa Kasus Disederhanakan, maka Metoda Optimasi yang dihasilkan masih harus disempurnakan. Penyempurnaan pertama bisa dilakukan dengan : penyertaan kendala Kapasitas Muatan Kendaraan Pengangkut, penyertaan kendala Urutan TA Pengambilan karena dipengaruhi oleh jaringan jalan yang ada, dan penyertaan kendala yang lain.

Untuk memudahkan penyebutan, Permasalahan Optimasi ini sebaiknya diberi nama sebagai berikut : Permasalahan Umum Pengangkutan dari $\mathrm{n}$ Titik Asal ke 1 Titik Pengumpulan. Metoda Optimasi yang dihasilkan dinamakan : Optimasi Jumlah Kendaraan Persinggahan dengan Kendala Waktu Kerja Kendaraan. Penamaan ini sesuai dengan sifat kasus yang ditangani.

Catatan. Penulisan makalah ini merupakan upaya persiapan bagi Penyusunan Tesis Magister Manajemen Aset Infrastruktur dengan topik mengenai Optimasi Pengangkutan Sampah Padat Tipe SCS. 


\section{DAFTAR PUSTAKA}

Baccelli, F., Cohen, G., Olsder, G.J. \& Quadrat, J-P. (1992). Synchronization and Linearity An Algebra for Discrete Event Systems. John Wiley \& Son. New York.

Bondy, J.A. \& Murty, U.S.R. (1982). Graph Theory with Applications. Fifth Printing. NorthHolland. New York.

Brandes, U. \& Erlebach, T. (1998). Network Analysis - Methodological Foundations. Springer, Berlin.

Dimyati, T.T. \& Dimyati A. (1994). Operation Research - Model-Model Pengambilan Keputusan. Sinar Baru Algesindo. Bandung.

Goldberg, A.W. (2000). "Basic Shortest Path Algorithms". DIKU Summer School on Shortest Paths. Microsoft Research. Silicon Valey.

Hillier, F.S. \& Lieberman, G.J. (1990). Introduction to Operation Research. Fifth Edition, Holden-Day Inc..San Francisco.

Indryani, R., Astana, I.N.Y. \& Suprayitno, H (2004). "Model Transportasi untuk Pengembangan Pelayanan Air Bersih di Kabupaten Badung Bali". Jurnal TORSI; Edisi Maret 2004, Tahun ke 24, No 1. Jurusan Teknik Sipil. Institut Teknologi Sepuluh Nopember (ITS). Surabaya.

Jaiswal, N.K. (1997). Military Operations Research : Quantitative Decision Making. Kluwer Academic. Boston.

Khan, Lutfar Rahman (1984). "Rural Road Planning in Developing Countries : A Network Modeling Approach". Disertation. Asian Institute of Technology. Bangkok.

Munir, Rinaldi (2003). Matematika Diskrit. Edisi Kedua. Penerbit Informatika. Bandung.

Schutter, B de. de \& Boom, T van den. de (2008). "Max-plus Algebra and Max-Plus Linear Discrete Event Systems : An Intoduction". Proceeding of $9^{\text {th }}$ International Workshop on Discrete Event Systems (WODES '08). Goteborg.

Srivastava, A.K. \& Nema, A.K. (2006), "Discussion of Multi-objectives Vehicle Routing and Scheduling Problem with Time Window Constraints in Hazardous Material Transportation", Journal of Transportation Engineering, September 2006, Vol. 132 No. 9, American Society of Civil Engineers, Reston, Virginia.

Suprayitno, Hitapriya \& Indryani, Retno (1997). "Masalah Transportasi Logisitk Kasus dengan Beberapa Titik Asal dan Beberapa Titik Tujuan". Jurnal TORSI, Edisi Nopember 1996, Tahun ke 16, No. 2. Jurusan Teknik Sipil. Institut Teknologi Sepuluh Nopember (ITS). Surabaya.

Suprayitno, Hitapriya \& Indryani, Retno (1997a). "Metoda Perhitungan Proporsi : Metoda Pemecahan Masalah Transportasi Logisitk". Jurnal TORSI, Edisi Mei 1997, Tahun ke 17, No. 1. Jurusan Teknik Sipil. Institut Teknologi Sepuluh Nopember (ITS). Surabaya.

Suprayitno, Hitapriya (1999). "Penyusunan Algoritma Bagi Pemecahan Permasalahan Optimasi Linier Umum Bersolusi Bilangan Bulat”. Jurnal TORSI, Edisi Mei 1999, Tahun ke 19, No. 1. Jurusan Teknik Sipil. Institut Teknologi Sepuluh Nopember (ITS). Surabaya.

Suprayitno, Hitapriya (2003). "Optimasi Permasalahan Armada dan Trayek Angkutan : Kasus Sederhana Pengangkutan Sampah dari TPS ke TPA". Jurnal TORSI, Edisi Juli 2003, Tahun ke 23, No 2. Jurusan Teknik Sipil. Institut Teknologi Sepuluh Nopember (ITS). Surabaya.

Suprayitno, Hitapriya (2008). "Algoritma Perhitungan Jarak Langsung Antar Titik pada Model Jaringan Hubungan Antar Titik", Seminar Nasional Teknik Sipil IV, Surabaya 13 Februari 2008. Jurusan Teknik Sipil. Institut Teknologi Sepuluh Nopember (ITS). Surabaya. 
Suprayitno, Hitapriya (2008). "Penggunaan Konsep Konektivitas Teori Graf sebagai Pijakan bagi Upaya Penyusunan Metoda Penilaian Kualitas Jaringan Jalan Primer'. Seminar Nasional Teknologi Infrastruktur Perkotaan, Surabaya 12 Juli 2008. Program Studi Diploma Teknik Sipil. Institut Teknologi Sepuluh Nopember. Surabaya.

Suprayitno, Hitapriya (2009). "Metoda Identifikasi Ketiadaan Graf Pohon berdasar Identifikasi Titik Terisolasi dan Busur Terisolasi pada Graf dengan Busur Tak Berarah dan Tak Berbobot". Seminar Nasional Teknik Sipil V, 11 Februari 2009. Jurusan Teknik Sipil. Institut Teknologi Sepuluh Nopember (ITS); Surabaya.

Suprayitno, Hitapriya (2010). "Identifikasi Graf Pohon Berbasis Aljabar Maks-Plus - Pada Graf Tak Berarah Tak Berbobot”. Seminar Nasional Teknik Sipil VI, 27 Januari 2010. Jurusan Teknik Sipil. Institut Teknologi Sepuluh Nopember (ITS). Surabaya. 